\title{
CHARACTERISTICS OF POLYMER COMPOSITES BASED ON NATURAL RUBBER
}

\author{
Maria Daniela STELESCU1*, Elena MĂNĂILĂ², Maria SÖNMEZ ${ }^{1}$, Mihaela NIJUICĂ ${ }^{1}$ \\ ${ }^{1}$ National Research and Development Institute for Textiles and Leather (INCDTP), Division Leather and Footwear Research \\ Institute (ICPI), 93 Ion Minulescu St., Bucharest, Romania, dmstelescu@yahoo.com \\ ${ }^{2}$ National Institute for Laser, Plasma and Radiation Physics, Electron Accelerators Laboratory, 409 Atomistilor St., 077125, \\ Magurele, Romania
}

Received: 30.05.2017

Accepted: 01.08.2017

https://doi.org/10.24264/Ifj.17.3.4

\section{CHARACTERISTICS OF POLYMER COMPOSITES BASED ON NATURAL RUBBER}

ABSTRACT. This paper presents the obtaining and characterization of new types of polymeric composites based on natural rubber and plasticized starch, crosslinked using peroxide in the presence of a polyfunctional monomer - trimethylolpropane trimethacrylate. Composite variants containing $10 \mathrm{phr}, 20 \mathrm{phr}, 30 \mathrm{phr}, 40 \mathrm{phr}$ and $50 \mathrm{phr}$ starch, respectively were made. Starch was plasticized and then incorporated in natural rubber in the roll mill, and then other ingredients were added; the resulting mixtures were cured in an electrical press. The physicomechanical characteristics of resulting composites depends on the amount of plasticized starch added to the rubber mixture. The results of liquid action on composites show that it depends on the behaviour of mixture components in immersion media; thus, natural rubber is water resistant (variation of mass and volume in water has very low values) but not resistant to toluene (variation of mass and volume in toluene has high values); starch is hydrophilic - it absorbs water and, with the increased amount of starch in the mixtures, there is also an increase of mass and volume variation in water, but the values obtained are good, with mass and volume variation after $22 \mathrm{~h}$ of water immersion being below $8 \%$. In toluene, there is an improvement in the behaviour of composites containing plasticized starch compared to control ones (without plasticized starch). The new polymer composites can be used in various fields such as in the food or pharmaceutical areas that require compositions free of toxic ingredients.

KEY WORDS: polymer composites, natural rubber, starch, characteristics

\section{CARACTERISTICILE UNOR COMPOZITE POLIMERICE PE BAZĂ DE CAUCIUC NATURAL}

REZUMAT. Această lucrare prezintă obţinerea şi caracterizarea unor noi tipuri de compozite polimerice pe bază de cauciuc natural şi amidon plastifiat, reticulate utilizând peroxid în prezenţa unui monomer polifuncţional - trimetilolpropan trimetacrilat. Compozitele au fost realizate cu conţinut de amidon $10 \mathrm{phr}, 20 \mathrm{phr}, 30 \mathrm{phr}, 40 \mathrm{phr}$ şi respectiv 50 phr. Amidonul a fost plastifiat şi apoi încorporat în cauciucul natural pe valţ, după care s-au adăugat celelalte ingrediente; amestecurile obţinute au fost vulcanizate în presa electrică. Caracteristicile fizicomecanice ale compozitelor obţinute depind de cantitatea de amidon plastifiat adăugat amestecului de cauciuc. Rezultatele acţiunii lichidelor asupra compozitelor arată că aceasta depinde de comportarea componentelor amestecului în mediul de imersie; astfel, cauciucul natural este rezistent la apă (variaţia masei şi volumului în apă având valori foarte mici), dar nu este rezistent la toluen (variaţia masei şi volumului în toluen are valori mari); amidonul este hidrofil - absoarbe apa şi, odată cu creşterea cantităţii de amidon din amestecuri, are loc şi o creştere a variaţiei masei şi volumului în apă, însă valorile obţinute sunt bune, variaţia masei şi volumului după 22 h de imersie în apă fiind sub $8 \%$. În toluen se observă o îmbunătăţire a comportării compozitelor care conţin amidon plastifiat faţă de cele martor (fără amidon plastifiat). Noile compozite polimerice pot fi utilizate în diferite domenii cum ar fi în domeniul alimentar sau farmaceutic, unde este cerută o compoziţie lipsită de ingrediente toxice.

CUVINTE CHEIE: compozite polimerice, cauciuc natural, amidon, caracteristici

LES CARACTÉRISTIQUES DES COMPOSITIONS POLYMÉRIQUES EN CAOUTCHOUC NATUREL

RÉSUMÉ. Cet article présente la production et la caractérisation de nouveaux types de caoutchouc polymère à base de caoutchouc naturel et d'amidon plastifié, réticulés à l'aide de peroxyde en présence d'un monomère polyfonctionnel trimetacrylate de triméthylolpropane. Les composites ont été fabriqués contenant $10 \mathrm{phr}, 20 \mathrm{phr}, 30 \mathrm{phr}, 40 \mathrm{phr}$ et $50 \mathrm{phr}$ d'amidon respectivement. L'amidon a été plastifié puis incorporé dans le caoutchouc naturel sur le rouleau, après quoi les autres ingrédients ont été ajoutés; les mélanges obtenus ont été vulcanisés dans la presse électrique. Les caractéristiques physico-mécaniques des composites obtenues dépendent de la quantité d’amidon plastifié ajoutée au mélange de caoutchouc. Les résultats de l'action des liquides sur les composites montrent que cela dépend du comportement des composants du mélange dans le milieu d'immersion ; ainsi, le caoutchouc naturel est résistant à l'eau (variation de la masse et du volume dans l'eau a des valeurs très faibles) mais il n'est pas résistant au toluène (la variation de la masse et du volume dans le toluène est élevée) ; l'amidon a une nature hydrophile - il absorbe l'eau et avec l'augmentation de la quantité d’amidon dans les mélanges, il y a aussi une augmentation de la variation de la masse et du volume dans l'eau, mais les valeurs obtenues sont bonnes, la variation de la masse et du volume après 22 heures d'immersion dans l'eau est au-dessous de $8 \%$. Dans le toluène a été observée une amélioration du comportement des composites contenant de l'amidon plastifié. Les nouveaux composites polymériques peuvent être utilisés dans divers domaines, comme dans le domaine alimentaire ou pharmaceutique, où une composition exempte d'ingrédients toxiques est nécessaire.

MOTS CLÉS: composites polymériques, caoutchouc naturel, amidon, caractéristiques * Correspondence to: Maria Daniela STELESCU, National Research and Development Institute for Textiles and Leather (INCDTP), Division
Leather and Footwear Research Institute (ICPI), 93 Ion Minulescu St., Bucharest, Romania, e-mail: dmstelescu@yahoo.com 


\section{INTRODUCTION}

The oldest and most important elastomer that was the first model for attempts to synthesize rubber is natural rubber. This elastomer is obtained from a series of laticiferous plants, such as Hevea brasiliensi, Ficus elastica etc. Natural rubber is used mainly in the tire industry, and at least currently it cannot be fully replaced with any other type of synthetic rubber. Its long fatigue life and high strength makes it suitable for use up to approximately $100^{\circ} \mathrm{C}$, and can maintain flexibility down to $-60^{\circ} \mathrm{C}$ in combination with other substances. Other advantages include good creep and stress relaxation resistance and low cost. In terms of disadvantages, natural rubber has poor oil resistance and no resistance to oxygen and ozone, which can however be improved by compounding with specific chemicals [1].

Natural rubber (NR) as such has very limited applications. Basically all technical products made of rubber are compositions in which the elastomer matrix embeds: curing agents curing accelerators, ingredients for reinforcement and other components with the role of facilitating processability, increasing resistance to degradation, colouring the final product, etc. Reinforcing elastomers with certain ingredients called fillers is a process of high practical and technological importance. The most commonly used are active fillers such as silica and carbon black. Silica is known to have adverse effects on health: silicosis, cancer (Group 1 according to IARC - the International Agency for Research on Cancer), autoimmune diseases, tuberculosis, kidney disease, and so forth, and in 1995, the IARC rated carbon black as IARC classification $2 \mathrm{~B}$-possibly carcinogenic to humans and definitely carcinogenic to animals [2-4]. Carbon black is the most commonly used filler in NR compounds. For food applications, most furnace blacks are considered safe. According to existing food regulations, the type and the amount of carbon black is limited. According to FDA 177.2600 , the amount of carbon black may not exceed $50 \%$ by weight of the rubber product. In rubber products intended for use in contact with milk or edible oils, the total carbon black amount may not exceed $10 \%$. According to German BgVV
Recommendation XXI, the only carbon blacks that are allowed are those that fulfill the criteria for cleanliness according to German BGesundBL 15,268 (1972) [5]. For these reasons, efforts were made to replace them with other types of fillers. Currently the most viable way toward eco-friendly composites is the use of natural fibers as reinforcement. Natural fibers represent a traditional class of renewable materials which, nowadays, are experiencing a great revival [6, 7]. On the other hand, natural fibers exhibit many advantageous properties which promote the replacement of synthetic fibers in polymer composites. They are a low-density material yielding relatively lightweight composites with high specific properties and therefore natural fibers offer a high potential for an outstanding reinforcement in lightweight structures.

In this paper the active filler was replaced with starch in the form of plasticized starch. Starch is an organic substance found in the seeds, fruits and tubers of plants and is used in the food, chemical and other industries. Starch comes from renewable resources and has many advantages, such as: low price, availability, non-toxicity, and it is widely used in many areas (food, paper manufacturing, chemical industry, packaging material industry, etc.) [8]. Starch can be altered by plasticization to improve its processability and other properties required for certain applications. Plasticizers bind macromolecules to high molecular mass compounds, thus leading to better processability. In the case of mixtures based on starch, tensile strength and flow properties may significantly improve through their conversion to plasticized starch using compounds such as water, glycerine or formamide, as the latter lead to more stable properties [8-9]. In this paper, starch was plasticized using water and glycerine.

The most important step of the technological process for developing rubber products is curing. Out of the several possibilities to crosslink natural rubber, the best known method is vulcanization with sulphur and curing accelerators. This occurs by ionic mechanism and leads to the formation of sulphur bridges between (C-Sx-C) macromolecules or cyclic combination of sulphur. Physical-mechanical properties of samples containing $\mathrm{C}-\mathrm{S} \mathrm{X}-\mathrm{C}$ crosslinking bridges 
exhibit better tensile strength values than those containing $\mathrm{C}-\mathrm{C}$ bonds. Although vulcanization with sulphur and vulcanization accelerators leads to obtaining products with better characteristics, it also has disadvantages, such as the fact that during the process of vulcanization nitrosamines (carcinogen products) are formed and the obtained end products are toxic, contain heavy metals $(Z n)$, have an unpleasant odor and exudate $[10,11]$. For these reasons, efforts are made internationally to replace sulfur and curing accelerators vulcanization systems. In this paper, crosslinking is done using peroxide in the presence of vulcanization co-agent. The use of organic peroxides is the only vulcanization method that can compete with accelerated sulphur cure, with respect to vulcanization rate. Peroxide vulcanisation leads to a rubber network in which the polymer chains are linked to each other by very stable covalent carboncarbon bonds. Peroxide cured vulcanisates have therefore good high temperature properties, like heat ageing and compression set, compared to sulphur cured articles [12-14].

This paper presents the process of obtaining and characterizing a new type of polymeric composite based on natural rubber and plasticized starch as filler, crosslinked using peroxide in the presence of a polyfunctional monomer - trimethylolpropane trimethacrylate. It also studies the influence of plasticized starch amount on the physical-mechanical properties and behaviour in aqueous and toluene environment.

\section{EXPERIMENTAL}

\section{Materials}

The following materials were used for rubber mixtures:

- Natural rubber (NR) for pharmaceutical use, Crep from Sangtvon Rubber Ltd, in the form of white rubber sheets, Mooney viscosity 67.64 $\mathrm{ML}\left(1^{\prime}+4^{\prime}\right) 100^{\circ} \mathrm{C}$, volatile matter content of $0.5 \%$, nitrogen content $0.45 \%$, ash content of $0.25 \%$, impurity content of $0.026 \%$;

- Starch - produced by Lach-Ner - soluble potato starch (water insoluble substances $0.28 \%$; loss on drying $16.9 \%$, easily biodegradable: $\mathrm{BOD}_{5}-$ $0.6 \mathrm{~g} / \mathrm{g}$ - and COD - $1.2 \mathrm{mg} / \mathrm{g}$ );

- Glycerine from SC Chimreactiv SRL (free acidity $0.02 \%$, density $1.26 \mathrm{~g} /$ $\mathrm{cm}^{3}$, purity $\left.99.5 \%\right)$;

- $\quad$ Richon IPPD antioxidant (4010 NA) $\mathrm{N}$-isopropyl - N-phenyl - phenylene diamine, $98 \%$ purity, molecular mass: 493.6374;

The following materials were used for crosslinking blends: Perkadox 40 benzoyl peroxide (density $160 \mathrm{~g} / \mathrm{cm}^{3}, 3.8 \%$ active oxygen content, $40 \%$ peroxide content, $\mathrm{pH} 7$ ) and Luvomaxx TMPT DL 75 (TMPT) trimethylolpropane trimethacrylate polyfunctional monomer (22\% ash, pH 9.2, density $1.36 \mathrm{~g} / \mathrm{cm}^{3}, 75 \pm 3 \%$ active ingredient).

\section{Plasticizing Starch}

Starch (50\%), water (20\%) and then glycerine $(30 \%)$ are mixed at $70^{\circ} \mathrm{C}$ for $15 \mathrm{~min}$ at $50-100 \mathrm{rpm}$ until a homogenous mixture is obtained. It is left for $1 \mathrm{~h}$ at room temperature, then in the oven for $22 \mathrm{~h}$ at $80^{\circ} \mathrm{C}$ and then for $2 \mathrm{~h}$ at $110^{\circ} \mathrm{C}$. It is left for $16 \mathrm{~h}$ in a dry place.

\section{Obtaining Polymer Composites}

The process of obtaining composite materials based on natural rubber and plasticized starch comprises: operations of characterizing raw materials, dosing raw materials and obtaining the composite by roller mixing.

Polymer composites based on natural rubber and plasticized starch consist of a rubber mixture whose composition is shown in Table 1. Mixtures were crosslinked with peroxide in the presence of a curing co-agent/polyfunctional monomer. The roller mixer working method is presented in Table 2. Roller mixer working parameters are: working temperature is kept below $60^{\circ} \mathrm{C}$, and friction is $1: 1,1$.

The products obtained as rubber mixtures in the form of sheets. These sheets were cured using molds and vulcanization press in order to obtain rubber plates with the sizes of $150 \mathrm{~mm} x$ $150 \mathrm{~mm} \times 2 \mathrm{~mm}$ required for die punching test specimens for the characterization of polymer composites. 
Table 1: Formulations

\begin{tabular}{lcccccc}
\hline Mixture symbol & $\begin{array}{l}\text { NR-0 } \\
(\mathrm{phr})\end{array}$ & $\begin{array}{l}\text { NR-10 } \\
(\mathrm{phr})\end{array}$ & $\begin{array}{l}\text { NR-20 } \\
(\mathrm{phr})\end{array}$ & $\begin{array}{l}\text { NR-30 } \\
(\mathrm{phr})\end{array}$ & $\begin{array}{l}\text { NR-40 } \\
(\mathrm{phr})\end{array}$ & $\begin{array}{l}\text { NR-50 } \\
(\mathrm{phr})\end{array}$ \\
\hline Natural rubber & 100 & 100 & 100 & 100 & 100 & 100 \\
Starch & - & $\mathbf{1 0}$ & $\mathbf{2 0}$ & $\mathbf{3 0}$ & $\mathbf{4 0}$ & $\mathbf{5 0}$ \\
Glycerine & - & 6 & 12 & 18 & 24 & 30 \\
Peroxide & 8 & 8 & 8 & 8 & 8 & 8 \\
TMPT & 3 & 3 & 3 & 3 & 3 & 3 \\
Antioxidant 4010 & 1 & 1 & 1 & 1 & 1 & 1 \\
\hline
\end{tabular}

Table 2: Roller mixer working method

\begin{tabular}{|c|c|}
\hline Order of adding ingredients & Time \\
\hline (1) Rubber is mixed in the roller mixer & ca. $2^{\prime}$ \\
\hline + (2) plasticized starch and glycerine & ca. $5^{\prime}-30^{\prime}$ \\
\hline$+(5)$ antioxidant & ca. $1^{\prime}$ \\
\hline$+(3)+(4)$ peroxide and TMPT & ca. $1^{\prime}$ \\
\hline Homogenisation & ca. $2^{\prime}$ \\
\hline Removing the mixture from the roller & ca. $1^{\prime}$ \\
\hline & $12-37^{\prime}$ \\
\hline
\end{tabular}

\section{Preparation of Sample}

Test specimen sheets of all compounds were produced using compression moulding. The temperature of the compression moulding machine was kept constant at $160^{\circ} \mathrm{C}$, for $20^{\prime}$ at a pressure of $300 \mathrm{kN}$. Cooling time $10^{\prime}$ at $25^{\circ} \mathrm{C}$ and $300 \mathrm{kN}$.

\section{Laboratory Tests}

\section{Physical-Mechanical Characteristics}

Tensile strength and tearing strength tests were carried out with a Schopper strength tester with testing speed $460 \mathrm{~mm} / \mathrm{min}$, using dumbbell shaped specimens according to ISO 37/2012, and angular test pieces (Type II) according to EN 12771/2003, respectively. Hardness was measured by using a hardness tester according to ISO 7619-1/2011 using 6-mm thick samples. Elasticity (rebound resilience) was evaluated with a Schob test machine using 6-mm thick samples, according to ISO 4662/2009.

\section{Determination of Liquid Action}

Determinations were performed according to ISO $1817 / 2015$ and the action of the following liquids was tested: water and toluene. The test pieces of known weight, $m_{\sigma}$ were immersed in various solvents in diffusion test bottles and kept at room temperature for 22 hours. After immersion the samples were taken out from the solvents and the wet surfaces were quickly dried using a tissue paper and re-weighted, $m_{i}$.

To calculate the percentage change in mass $\Delta m_{100}$ the following formula was used (1):

$$
\Delta m_{100}=\frac{m_{i}-m_{0}}{m_{0}} \times 100
$$

where $m_{0}$ is the initial mass of the test piece and $m_{\mathrm{i}}$ is the mass of the test piece after immersion. 
To calculate the percentage change in volume $\Delta V_{100}$ the following formula was used (2):

$$
\Delta V_{100}=\left(\frac{m_{i}-m_{i, w}+m_{s, w}}{m_{0}-m_{0, w}+m_{s, w}}-1\right) x 100
$$

where:

- $m_{0, w}$ is the initial mass of the test piece (plus sinker if used) in water;

- $m_{i, w}$ is the mass of the test piece (plus sinker if used) after immersion in water;

- $m_{s, w}$ is the mass of the sinker, if used, in water.

The result was reported as the median value for the three test pieces.

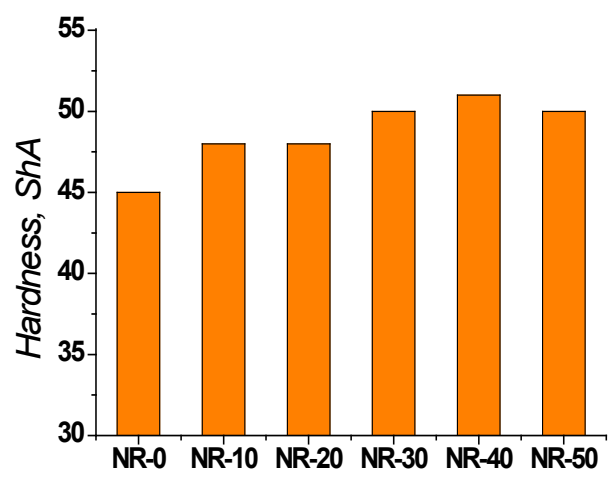

Figure 1. Hardness variation depending on the amount of plasticized starch introduced in the mixture

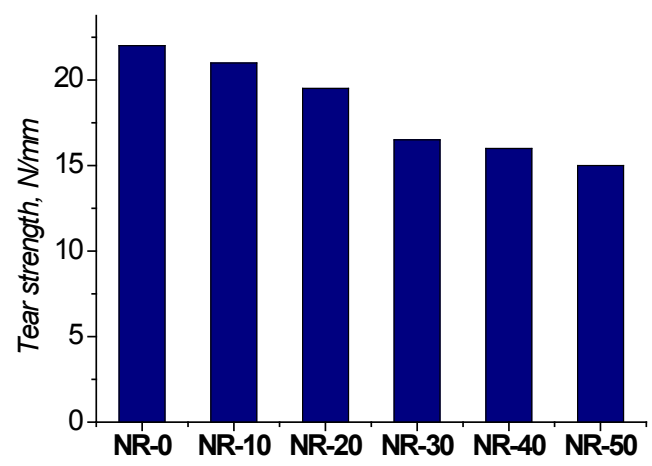

Figure 3. Tear strength variation depending on the amount of plasticized starch introduced in the mixture

\section{RESULTS AND DISCUSSIONS}

\section{Physical-Mechanical Characteristics}

The influence of the plasticized starch amount on the physical-mechanical characteristics of mixtures is illustrated in Figures 1-5. Analyzing the physical-mechanical characteristics of mixtures based on natural rubber and plasticized starch, it can be noticed that when increasing the amount of starch in the mixtures: (a) hardness (Figure 1) increases indicating that starch leads to NR reinforcement, (b) elasticity (Figure 2) decreased as a result of lowering the amount of natural rubber in the mixtures and reinforcing the mixtures; (c) tear strength (Figure 3) decreased, and tensile strength (Figure 4) improved, however it shows a

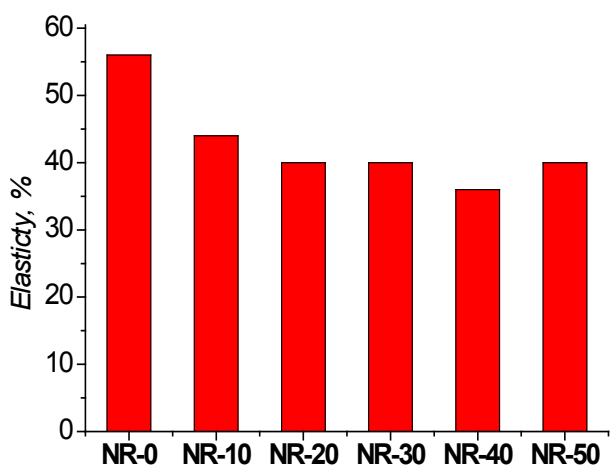

Figure 2. Elasticity variation depending on the amount of plasticized starch introduced in the mixture

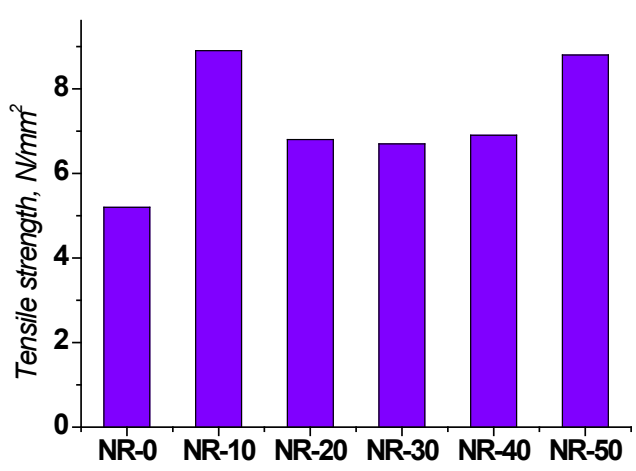

Figure 4. Tensile strength variation depending on the amount of plasticized starch introduced in the mixture 


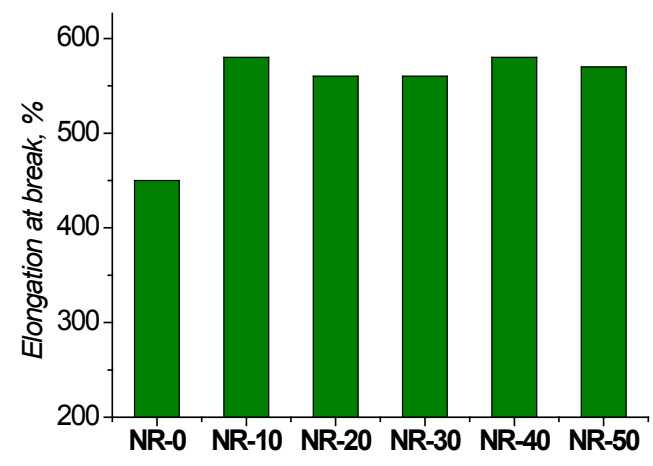

Figure 5. Elongation at break variation depending on the amount of plasticized starch introduced in the mixture

non-uniform variation to increasing the amount of starch; (d) elongation at break (Figure 5) shows a non-uniform increase with the increase of plasticized starch amount. The data shows that plasticized starch may replace active fillers such as carbon black or precipitated silica which are harmful and may cause occupational illnesses to employees in the rubber processing industry.

\section{Action of Liquids on Composites}

The results of liquid action on composites are presented in Figures 6-7. The data show

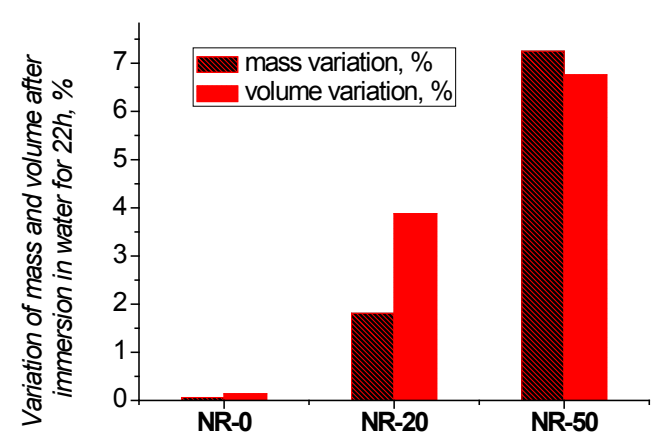

Figure 6. Variation of mass and volume after immersion in water for $22 \mathrm{~h}$

\section{CONCLUSIONS}

A new type of polymeric composites based on natural rubber and plasticized starch as filler was obtained and characterized, crosslinked using peroxide in the presence of that it depends on the behaviour of mixture components in immersion media; thus, natural rubber is water resistant (variation of mass and volume in water has very low values) but not resistant to toluene (variation of mass and volume in toluene has high values); starch has a hydrophilic nature - it absorbs water and, with the increased amount of starch in the mixtures, there is also an increase of mass and volume variation in water.

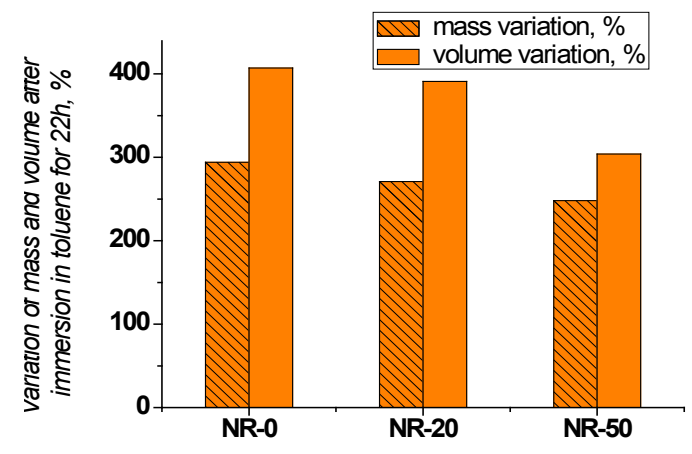

Figure 7. Variation of mass and volume after immersion in toluene for $22 \mathrm{~h}$

trimethylolpropane trimethacrylate. These composites have good physical-mechanical characteristics, indicating that plasticized starch may successfully replace inorganic fillers in rubber mixtures, which are harmful and may cause occupational illnesses to employees in the 
rubber processing industry. The results of liquid action on composites show that it depends on the behaviour of mixture components in immersion media; thus, natural rubber is water resistant (variation of mass and volume in water has very low values) but not resistant to toluene (variation of mass and volume in toluene has high values); starch has a hydrophilic nature - it absorbs water and, with the increased amount of starch in the mixtures, there is also an increase of mass and volume variation in water, however the values obtained are good, mass and volume variation after $22 \mathrm{~h}$ of immersion being below $8 \%$. In toluene, an improvement is seen in the behaviour of composites containing plasticized starch compared to control samples.

The new polymer composites may be used in various areas such as the food or pharmaceutical industry that requires compositions free of toxic ingredients.

\section{Acknowledgements}

This research was financed through Nucleu Program 2016-2017, project PN 163401 01: “Development of biodegradable nanocomposites based on natural rubber, starch and OMMT with applications in the food and pharmaceutical industries" by Romanian Ministry of Research and Innovation.

\section{REFERENCES}

1. Manaila, E., Craciun, G., Stelescu, M.D., Ighigeanu, D., Ficai, M., Radiation Vulcanization of Natural Rubber with Polyfunctional Monomers, Polym Bull, 2014, 71, 57-82.

2. IARC Working Group on the Evaluation of Carcinogenic Risks to Humans, Silica, Some Silicates, Coal Dust and Para-Aramid Fibrils, IARC Monographs on the Evaluation of Carcinogenic Risks to Humans, vol. 68, World Health Organization, Lyon, 1997, http:// monographs.iarc.fr/ENG/ Monographs/ vol68/index.php. Accessed 18 Sep 2014.
3. Beliczky, L.S., Fajen, J., Rubber Industry, in J.M. Stellman (Ed.), Encyclopaedia of Occupational Health and Safety, chapter 80, International Labor Office, Geneva, Switzerland, 4th edition, 1998.

4. Stelescu, M.D., Manaila, E., Craciun, G., Dumitrascu, M., New Green Polymeric Composites Based on Hemp and Natural Rubber Processed by Electron Beam Irradiation, Scientific World J, Volume 2014, Article ID 684047, http://dx.doi. org/10.1155/2014/684047.

5. De Coster, N., Magg, H., Leverkusen, NBR in Contact with Food, Potable Water, Pharmaceutical and Cosmetic Applications, KGK Kautschuk Gummi Kunststoffe, 56. Jahrgang, Nr. 7-8, 2003.

6. Manaila E., Stelescu, M.D., Doroftei, F., Polymeric Composites Based On Natural Rubber And Hemp Fibers, Iran Polym J, 2015, 24, 2, 135-148.

7. Cristaldi, G., Latteri, A., Recca, G., Cicala, G., Composites Based on Natural Fibre Fabrics, in P.D. Dubrovski (Ed.), Woven Fabric Engineering, Sciyo, Rijeka, Croatia, Published Online 18 August, 2010, 318-342, www. Intechopen.Com, accessed 2 June 2014.

8. Wu, Y.-P., Qi, Q., Liang, G.-H., Zhang, L.-Q., A Strategy to Prepare High Performance Starch/ Rubber Composites: In situ Modification during Latex Compounding Process, Carbohydr Polym, 2006, 65, 109-113.

9. Shey, J., Imam, S.H., Glenn, G.M., Orts, W.J., Properties of Baked Starch Foam with Natural Rubber Latex, Ind Crops Prod, 2006, 24, 1, 3440.

10. Stelescu, M.D., Manaila, E., Craciun, G., Vulcanization of Ethylene-PropyleneTerpolymer-based Rubber Mixtures by Radiation Processing, J Appl Polym Sci, 2012, 128, 2325-2336. 
11. Gonzalez, L., Rodriguez, A., MarcosFernandez, A., Chamorro, C., A New Interpretation of the Crosslinking Mechanism of NR with Dicumyl Peroxide, Kautsch Gummi Kunstst, 1998, 51, 2, 83-87.

12. Gonzalez, L., Rodriguez, A., Valentin, J.L., Marcos-Fernandez, A., Posadas, P., Conventional and Efficient Crosslinking of Natural Rubber, Kautsch Gummi Kunstst, 2005, 58, 638-643.

13. Ikarashi, Y., Toyoda, K., Ohasawa, N., Uchima, T., Tsuchiya, T., Kaniwa, M.A., Sato, M., Takahashi, M., Nakamura, A., Comparative Studies by Cell Culture and in vivo Implantation Test on the Toxicity of Natural Rubber Latex Materials, J Biomed Mater Res, 1992, 26, 3, 339-356.
14. Dluzneski, P.R., Peroxide Vulcanization of Elastomers, Rubber Chem Technol, 2001, 74, 3, 451-492.

(C) 2017 by the author(s). Published by INCDTP-ICPI, Bucharest, RO. This is an open access article distributed under the terms and conditions of the Creative Commons Attribution license (http://creativecommons.org/licenses/ by/4.0/). 